\title{
Overgrowth competition in an assemblage of encrusting bryozoans settled on artificial substrata
}

\author{
J. J. López Gappa \\ Consejo Nacional de Investigaciones Científicas y Técnicas (CONICET), Museo Argentino de Ciencias Naturales \\ 'B. Rivadavia', Avda. Angel Gallardo 470, 1405 Buenos Aires, Argentina
}

\begin{abstract}
Patterns of intra- and interspecific competition on artificial substrata were studied in Patagonia, in an epifaunal community composed of 19 species of bryozoans, 4 spirorbid polychaetes and 1 colonial tunicate. The latter was found to be dominant over bryozoans and both groups were able to overgrow spirorbids. Apparent cessation of growth occurred in intraspecific encounters among bryozoan colonies. Several cases of homosyndrome were recorded in the dominant species Umbonula alvareziana. Competitive ability was correlated with zoarial height in cheilostome but not in cyclostome bryozoans. Lack of correlation between abundance and competitive ability could be related to the relatively early successional stage of this assemblage, where a high proportion of the surface is bare. Analysis of the interaction matrix indicates a clearly hierarchical competitive organization of the community. Colony size was found to be an important factor influencing the outcome only in encounters between species with similar competitive abilities. Relationships among number of ovicells, colony shape and overgrowth ability were analyzed in 2 closely related species of Celleporella: the runner-like C. patagonica compensates its poor competitive performance by reaching sexual maturity earlier and having a significantly higher rate of ovicell production than the sheet-like C. yagana.
\end{abstract}

\section{INTRODUCTION}

Studies on competitive overgrowth interactions among encrusting invertebrates in epifaunal communities have increased considerably in recent years. Since substratum availability is often the limiting factor in sessile benthic assemblages (Connell 1961, Dayton 1971, Paine 1974, Jackson 1977a, Osman 1977), mechanisms for acquiring and holding space are fundamental for both solitary and colonial organisms. Data on competitive interference abilities have been obtained in different temperate and tropical habitats, such as coral undersurfaces (Jackson \& Buss 1975, Buss \& Jackson 1979, Jackson 1979a), intertidal and subtidal hard bottoms (Gordon 1972, Osman 1977, Buss 1980a, b, 1981, Quinn 1982, Rubin 1982, Paine 1984), algae (Stebbing 1973a, b, O'Connor et al. 1980), hermit crab shells (Karlson \& Shenk 1983) and artificial substrata (Keen \& Neill 1980, Russ 1982). Competition for space has also been studied in fossil epifaunas by Taylor (1979, 1984) and Liddell \& Brett (1982).

This paper analyzes patterns of overgrowth competition in a Patagonian bryozoan community growing on artificial panels, as well as the relationships among competitive ability, ovicell production and morphological characteristics in some of the most frequent species. Although the present study focused mainly on intraand interspecific competition among bryozoan colonies, some observations on overgrowth abilities of spirorbids and a colonial tunicate are also included.

\section{STUDY AREA AND METHODS}

The study was carried out at Puerto Deseado, Santa Cruz, Argentina $\left(47^{\circ} 45^{\prime} \mathrm{S}, 65^{\circ} 55^{\prime} \mathrm{W}\right)$, which is located on the northern shore of an estuary about $40 \mathrm{~km}$ in length and oriented in an E-W direction in its outer zone. Water temperatures are typically subantarctic and influenced by the Malvinas Current, varying from about $4.5^{\circ} \mathrm{C}$ in winter to $13.5^{\circ} \mathrm{C}$ in summer. Extreme tide amplitude reaches almost $6 \mathrm{~m}$, producing strong tidal currents. Salinity varies around $33 \%$. Kühnemann (1970) has described the Puerto Deseado area in more detail

Ten sand-blasted acrylic panels $(24 \times 14 \times 0.2 \mathrm{~cm})$ were provided as surfaces for settlement and growth of sessile organisms (Fig, 1). They were screwed to a 
rectangular iron frame in 2 superposed series of 5 adjoining panels. The whole set was maintained in a vertical position ca $2 \mathrm{~m}$ beneath low tide level for 9 mo (1 April to 28 December 1977). Panels were then fixed in $5 \%$ formalin, rinsed in water, air-dried and examined under a stereomicroscope.

Percentage cover of each species was estimated by point sampling (Jackson 1977b, 1979a, Sutherland \& Karlson 1977, Russ 1980). One hundred random points were marked on a transparent sheet which was laid on the panels and organisms underlying these points were recorded. Percentages were then calculated from data pooled over all panels.

Following Stebbing (1973a), overgrowth in bryozoans was defined as the elevation of the growing edge of a colony over another so as to cover the apertures of zooids. All cases of competitive interaction between bryozoan species were counted, with the exception of intraspecific competition in Umbonula alvareziana, in which a maximum of 100 encounters was examined. The methodology proposed by Russ (1982) for statistical treatment of interspecific overgrowth, as well as the arrangement of data in matrices of competitive interaction, was adopted. Species involved in 5 or less encounters were not included in the matrix. Chi-square 1 -sample tests were performed on interactions with 5 or more cases, so as to test the null hypothesis that no differences in competitive ability exist between both competitors (1 degree of freedom, $\alpha=0.05$ ). In interactions with ties (i.e. apparent cessation of growth on the line of contact between colonies), a score was calculated for each species, made up of the sum of 2 points for each win plus 1 point for each tie. The chi-square test was then performed on these scores (Russ 1982).

In order to test the influence of zoarial size on the outcomes between species with similar competitive ability, an interaction matrix was calculated among 7 of the 12 studied bryozoans, taking into account the relative size of both colonies. Species with very poor overgrowth abilities, which generally showed low proportions of ties and reversals, were not included in this matrix.

As a measure of competitive ability the wins/losses ratio ( $\mathrm{W} / \mathrm{L}$ ) of each bryozoan species was calculated (Jackson 1979a).

Zoarial type, number of spines in marginal zooids and marginal thickness of the colony (including spines) were also recorded for the 12 most frequent bryozoan species, in order to relate overgrowth ability with morphologic characteristics of zooids and zoaria. Values for these 12 species (Table 1 ) were ranked for percentage cover, W/L ratio and colony thickness. Paired correlations were calculated using Spearman's rank order coefficient (Siegel 1956).
An index proposed by Rubin (1982) was used to measure the degree of intransitivity of the assemblage:

$$
\left(\sum_{i=1}^{n} \frac{\sum_{j=1}^{n} \mathrm{P}_{i j}[\mathrm{~W}]}{\sum_{j=1}^{n} \mathrm{P}_{i j}[\mathrm{~L}]}\right) \div n
$$

where $\mathrm{P}_{1 j}[\mathrm{~W}]=$ probability that species $i$ will overgrow species $j_{i} P_{i j}[L]=$ probability that species $i$ is overgrown by species $j_{i} n=$ number of species. This index yields a value of 1 in a perfectly intransitive association. However, a value of $\infty$ is obtained in a perfectly transitive relationship, which would be inadequate as a definition for the upper limit of the index. To overcome this problem, Rubin (1982) calculated values of nearperfect transitivity of $3.37,4.09,4.61,5.01,5.32$ and 5.57 for associations of $3,4,5,6,7$ and 8 species respectively, giving each species a $\mathrm{P}_{i j}[\mathrm{~L}]=0.1$ in its cncounters with the 2 immediately below in the hierarchy.

In order to compare the rates of ovicell production of Celleporella yagana and C. patagonica, 30 ovicelled colonies of each species were randomly chosen among those having unobstructed growing margins. Obstructed colonies were discarded because growth detention is likely to produce some effect on ovicell production. Numbers of ovicells and zooids were counted on camera lucida drawings of the colonies. Indirect computation of zooid number by measurement of colony area (only applicable in this case to $C$. yagana) was avoided, for it would have introduced a bias in the data. As a previous step in the analysis, a third-order polynomial regression of ovicell number over zooid number was fitted in both species by means of the POLY program of the statistical package BIOM (Rohlf 1982). Results of this analysis indicate that the functional relation between both variables can be adequately accounted for by a linear model in C. yagana. On the other hand, C. patagonica seems to show a slight trend to curvilinearity. However, while the linear term is highly significant $(P<0.001)$, the quadratic term scarcely reaches significance $(0.05>P>0.01)$. As a consequence, a linear model was also fitted in this species, and considered valid until more data can be gathered about its reproductive pattern. The functional relation between ovicell and zooid number are described by the slope of the major axis of the confidence ellipses in a Model II regression (Sokal \& Rohlf 1981).

\section{RESULTS}

Bryozoans were the dominant organisms in this assemblage at the time of observation, with a percentage cover of $57.5 \%$, while spirorbid polychaetes and 


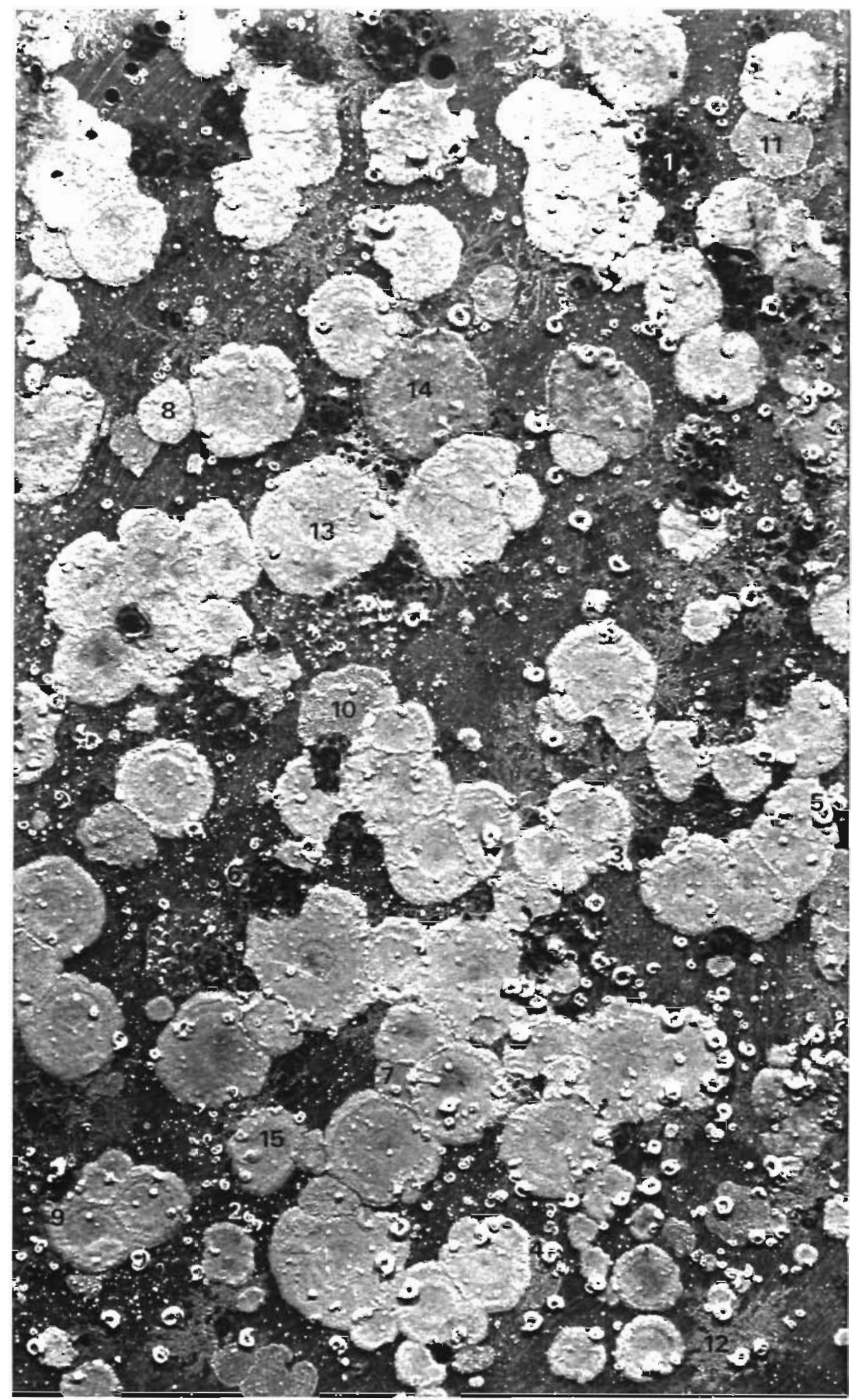

Fig. 1. Surface of a panel after 9 mo of exposure. 1, Aplidıum sp. (tunıcate): 2, Paralaeospira levinsenı, 3, Protolaeospira lebrunı, 4 , Romanchella perrieri, 5, Romanchella sp. (polychaetes), 6, Tubulpora organisans. 7, Andreella patagonca. 8, Smittina monacha. 9. Celleporella hyalina. 10, C. bougainvillei. 11, C. yagana. 12, C. patagonica. 13, Umbonula alvarezlana. 14, Arachnopusia monoceros. 15, Exochella longirostns (bryozoans) 
Table 1 Percentage cover, wins/losses ratio, number of spines in marginal zooids, colony thickness and zoarial type in 12 bryozoan species involved in more than 5 encounters. Species arranged in order of decreasing percentage cover. Symbols for species (in brackets) as in. Figs. 2 and 3. Zoarial type symbols: SL, single-layered; ML, multilayered: M, multiserial; U, uniserial; L, lobulated. Other bryozoan species include Alcyonidium polyoum (Hassal). Fenestrulina majuscula Hayward, Osthimosia eatonensis (Busk), Beania magellanica (Busk), Codonellina galeata (Busk), Electra monostachys (Busk) and Diastopora sp.

\begin{tabular}{|c|c|c|c|c|c|}
\hline Species & $\begin{array}{c}\text { Percentage } \\
\text { cover }\end{array}$ & $\begin{array}{l}W / L \\
\text { ratio }\end{array}$ & $\begin{array}{c}\text { Spines in } \\
\text { marginal } \\
\text { zooids }\end{array}$ & $\begin{array}{c}\text { Colony } \\
\text { thickness } \\
\text { (mm) }\end{array}$ & $\begin{array}{l}\text { Zoarial } \\
\text { type }\end{array}$ \\
\hline Umbonula alvareziana (d'Orbigny) (Ua) & 37.6 & 31.93 & $2-4$ & 0.55 & $S L, M$ \\
\hline Celleporella patagonica (Busk) (Cp) & 7.8 & 0.00 & - & 0.14 & SL, U \\
\hline Celleporella yagana Moyano \& Gordon (Cy) & 2.8 & 0.24 & - & 0.18 & $\mathrm{SL}, \mathrm{M}$ \\
\hline Exochella longirostris Jullien ( $\mathrm{El}$ ) & 2.8 & 2.64 & $3-4$ & 0.32 & $S L, M$ \\
\hline Smittina monacha (Jullien) (Sm) & 1.5 & 1.06 & $2-5$ & 0.42 & $\mathrm{SL} / \mathrm{ML}, \mathrm{M}$ \\
\hline Arachnopusia monoceros (Busk) (Am) & 1.1 & 11.00 & $3-4$ & 0.79 & $S L, M$ \\
\hline Celleporella bougainvillei (d'Orbigny) (Cb) & 1.1 & 0.16 & 2 (small) & 0.24 & $S L, M$ \\
\hline Celleporella hyalina (Linné) (Ch) & 0.6 & 4.50 & - & 0.30 & ML, M \\
\hline Hippadenella margaritifera (Quoy \& Gaimard) (Hm) & 0.4 & 5.00 & - & 0.40 & SL, M \\
\hline Tubulipora stellata Busk (Ts) & 0.4 & 0.42 & - & 0.81 & SL, M (L) \\
\hline Andreella patagonica López Gappa (Ap) & 0.3 & 0.91 & - & 0.36 & $\mathrm{SL}, \mathrm{M}$ \\
\hline Tubulppora organisans d'Orbigny (To) & 0.1 & 0.23 & - & 0.95 & SL, M \\
\hline Other bryozoan species & 0.9 & & & & \\
\hline
\end{tabular}

the colonial tunicate Aplidium sp. occupied $8.3 \%$ and $9.2 \%$ of the surface respectively. Bare space represented $24.9 \%$ of the substratum (Fig. 1).

Percentage cover of the 12 most abundant bryozoans is shown in Table 1. Umbonula alvareziana was by far the most common species in the community $(37.6 \%)$, accounting for $65.4 \%$ of the bryozoan total.

Spirorbid polychaetes were represented by 4 species: Romanchella perrieri (Caullery \& Mesnil), Paralaeospira levinseni (Caullery \& Mesnil), Protolaeospira lebruni (Caullery \& Mesnil) and Romanchella sp. As no specific differences were noted in their competitive abilities against bryozoans and Aplidium, they are discussed together.

Encounters between Aplidium-bryozoans, Aplidiumspirorbids and bryozoans-spirorbids were numerous on the panels. They invariably rendered the same results and were therefore not quantified. Aplidium was clearly dominant over all bryozoans and spirorbids, overgrowing even the largest colonies of Umbonula alvareziana and Arachnopusia monoceros. No spirorbid settlement was seen on the surface of this tunicate

Bryozoans clearly dominated over spirorbids in the competition for space on the panels. Small tubes of newly settled polychaetes were easily overgrown by the growing margin of sheet-like colonies. They were often completely covered and only visible by a basal examination of detached zoaria. Larger specimens were more difficult to overgrow. A common response by the polychaetes in these cases was the modification of the curve of the outer whorl so as to grow onto the inner whorls and become raised off the substratum. This response seemed to be more effective in those instances in which the polychaete had attained a considerable size before the encounter. While small and medium-sized individuals were often completely occluded, larger ones were more frequently seen with only the orifice projecting off the bryozoan zoarium.

Celleporella patagonica seems to be the only bryozoan which is unable to overgrow spirorbid worms. In the majority of instances growth of the uniserial zoarium appears to have been redirected around the tubes.

Settlement of juvenile spirorbids was often observed on older (i.e. central) parts of Umbonula alvareziana and other sheet-like species.

Data on intraspecific competition appear in the main diagonal of Fig. 2. Only in the cases of Umbonula alvareziana and Celleporella yagana could sufficient information be obtained. It confirms the well-established fact that zoaria of the same species generally stop growing where they meet (Knight-Jones \& Moyse 1961, Hayward 1973. Stebbing 1973a, b, Osman 1977. Seed \& O'Connor 1981, Cancino 1986). Growth of these colonies continues along those parts of the growing edge where no obstacles exist. Only 2 cases of large $U$. alvareziana overgrowing very small colonies of the same species were observed.

During the present study, several probable examples of homosyndrome were observed between colonies of Umbonula alvareziana. Examined colonies in which fusion had occurred were of approximately similar sizes. An inconspicuous crest formed in the central part, where zooids encounter each other frontally. In peripheral areas, however, rows become parallel and finally fuse completely, forming a common growing 
edge. As a result of this process, 1 circular colony with 2 separate ancestrulae and zones of astogenetic change is formed.

A total of 1405 interspecific encounters among the 19 bryozoan species was recorded. Overgrowth was observed in 1182 cases $(84.1 \%)$ and apparent cessation of growth in the other $223(15.9 \%)$.

Interspecific competition among 12 bryozoan species involved in more than 5 encounters is shown in Fig. 2. Umbonula alvareziana was the most abundant species of the community and the only one for which interactions with most other bryozoans could be statistically tested. The competitive dominance of $U$. alvareziana over Celleporella patagonica, C. yagana, C. bougainvillei, Tubulipora stellata, T. organisans and Andreella patagonica is clear, with very few cases of ties and reversals.

On the other hand, encounters between Umbonula alvareziana and Smittina monacha, Exochella longirostris, Celleporella hyalina and Hippadenella margaritifera showed a different pattern. Ties were the most frequent outcome, suggesting similar competitive abilities vis-a-vis these 4 species. While against C. hyalina and $H$. margaritifera there was no clear winner, $U$. alvareziana won in the other 2 cases. However, an analysis of these 2 interactions, shown in Fig. 3, reveals that the dominance of $U$. alvareziana over E. longiros- tris and $S$. monacha is related to size frequency of its colonies, which are larger than those of its competitors in most instances

Arachnopusia monoceros seems to be the only frequent bryozoan that won in competition with Umbonula alvareziana. A. monoceros clearly dominated when its colonies were larger In contrast, ties commonly occurred when $U$. alvareziana was larger (Fig. 3). However, scores obtained by both species in the $\mathrm{W} / \mathrm{L}$ ratio are distorted by the greater abundance of $U$. alvareziana and do not reflect the dominance of $A$. monoceros in this interaction (Table 1).

A response of the nearly circular colonies of Tubulipora organisans against Umbonula alvareziana is the elevation of the growing edge off the substratum. The same was observed by Stebbing (1973b) in another 2 cyclostomes. Although this can be effective in some cases, $U$. alvareziana often climbs over it, begins covering the basal parts of the zooids and sometimes also overgrows the peristomes. On the other hand, the zoarial type of $T$. stellata, with lobulated arms, makes this species more vulnerable than $T$. organisans to growth of $U$. alvareziana.

Although the number of cases is not enough to reach statistical significance, 2 other rare bryozoans seem to have high competitive abilities. Beania magellanica was found anchored with the root-like extremities of its

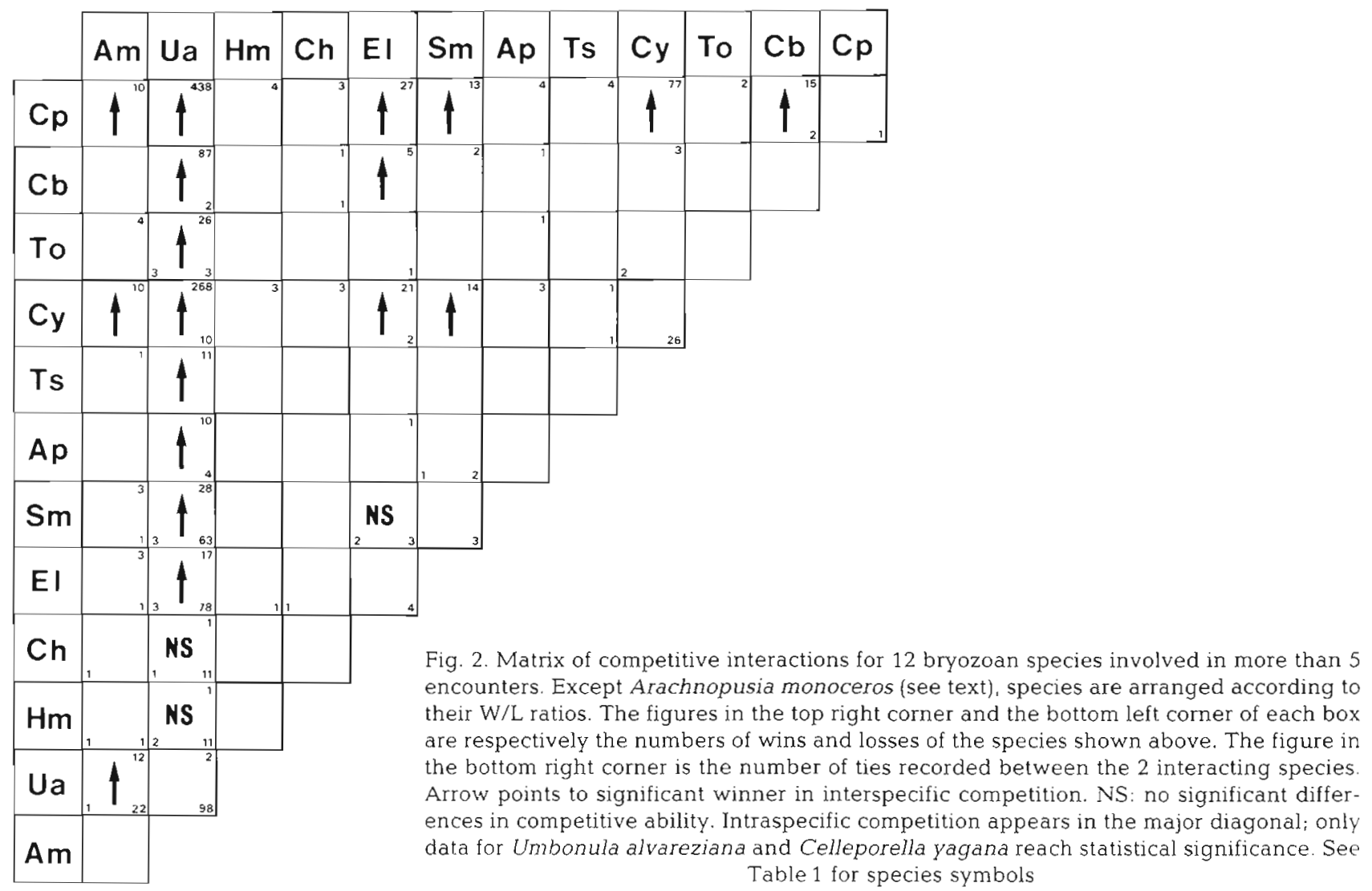




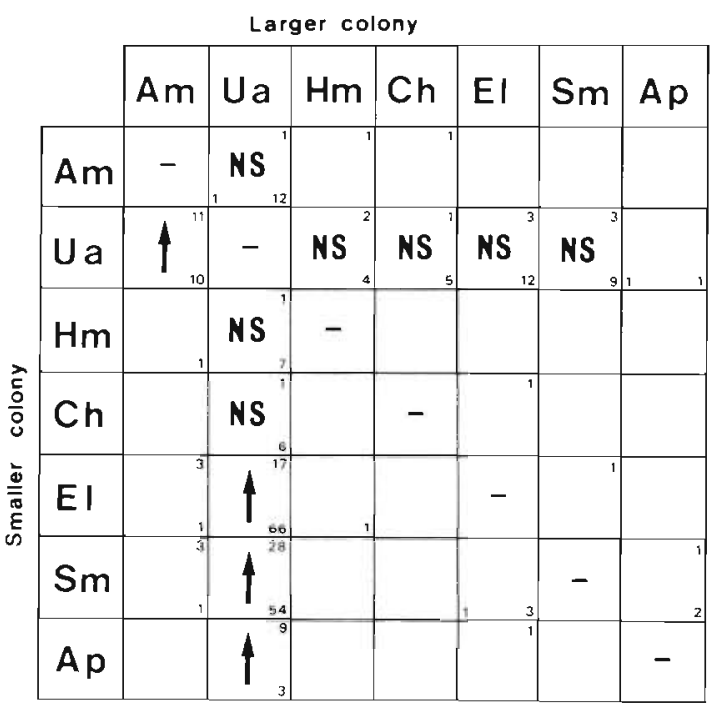

Fig. 3. Matrix of interspecific competitive interactions for 7 bryozoan species, taking into account relative size of interacting colonies. See Table 1 for species symbols; Fig. 2 for explanation

kenozooidal tubes to 1 zoarium of Arachnopusia monoceros, 1 of Hippadenella margaritifera and 2 of Umbonula alvareziana. The latter was also covered by an uncalcified and flexible colony of the ctenostome Alcyonidium polyoum in 1 case.

Correlation between percentage cover and competitive ability of bryozoan species measured by the W/L ratio (Table 1) does not differ significantly from zero $\left(r_{\mathrm{S}}=0.11, p>0.05\right)$. This is because species with high competitive abilities, such as Arachoposia monoceros, Hippadenella margaritifera and Celleporella hyalina are relatively scarce on the panels. In contrast, C.patagonica, the second most abundant bryozoan, has the lowest competitive ability in the community.

The null hypothesis that there was no correlation between colony thickness and competitive ability, measured by the W/L ratio, cannot be rejected $\left(r_{\mathrm{s}}=\right.$ $0.38, p>0.05)$. The greatest contribution to differences in ranks was due to the cyclostomes, Tubulipora organisans and $T$. stellata. These species have the tallest zooids in the assemblage but very low values for the $W / L$ ratio (Table 1 ). However, if the same test is carried out taking into account only cheilostome species, correlation becomes highly significant $\left(r_{\mathrm{s}}=\right.$ $0.83, p<0.01$ )

Differences in zoarial height among spiny cheilostomes (Umbonula alvareziana, Arachnopusia monoceros, Exochella longirostris, Smittina monacha) were relatively small (Table 1). A high proportion of ties is observed in encounters among these species (Figs. 2 and 3). On the other hand, colony thicknesses of $A$. monoceros and $U$. alvareziana are from 3 to more than 5 times greater than those of Celleporella patagonica and C. Yagana. Differences are in these instances so important that this factor becomes the main determinant of the outcome.

With the exception of Celleporella patagonica and Tubulipora stellata, all bryozoans in this community develop colonies of approximately circular shape after early stages of astogeny (Table 1). As a consequence, an overwhelming proportion of intra- and interspecific encounters were found to be frontal (Fig. 1), with very few lateral and rear encounters. Therefore, the influence of the encounter angle on competitive relationships could not be quantitatively evaluated.

The index proposed by Rubin (1982) was applied to overgrowth data of Fig. 2. Since one of the conditions to use this index is that all species in the matrix must encounter one another at least once, calculations could be done only in the 6 most frequent species (Umbonula alvareziana, Celleporella patagonica, C. yagana, Exochella longirostris, Smittina monacha, Arachnopusia monoceros). Since A. monoceros loses in only 1 opportunity, the index reaches a value of 11.23 , exceeding the figure for near-perfect transitivity for 6 species obtained by Rubin (5.01). Excluding A. monoceros from the calculations, a result of 3.99 is obtained, which approaches the maximum theoretical value for 5 species (4.61).

Celleporella patagonica has the lowest W/L ratio in the community (Table 1), losing in its interactions with all other species. C. yagana and C. bougainvillei also have low competitive abilities. They are overgrown by cheilostomes with spiny and taller marginal zooids, such as Umbonula alvareziana, Exochella Iongirostris, Arachnopusia monoceros and Smittina monacha (Table 1; Fig. 2). Their sheet-like colonies are, however, dominant over the runner-like ones of C. patagonica. Fig. 4 shows the relation between number of ovicells and number of zooids in C. yagana and C. patagonica. The expected number of zooids needed to produce the first ovicell (calculated from the regression line) is lower in $C$. patagonica (122), than in C. yagana (213). The smallest observed colonies on panels had 74 zooids with 12 ovicells in C. patagonica, and 180 zooids with 3 ovicells in C. Yagana (Fig. 4). Four colonies with only 1 ovicell were found among abundant material of Celleporella spp. growing on laminar red algae from Puerto Deseado (Mus. Arg. Cienc. Nat. Nos. 32211 and 32251). Three of them corresponded to C. patagonica and had 26, 37 and 48 zooids, while the fourth (C. yagana) had 200 zooids. Therefore, both expected and observed data indicate an earlier onset of sexual reproduction in C. patagonica. In addition, the $95 \%$ confidence intervals for the slope of the major axes do not overlap (Fig, 4), showing a significantly higher rate of ovicell production in the branching, uniserial species. The average number of zooids per $\mathrm{cm}^{2}$ is higher in C. yagana (1022, range: 854 
Fig. 4. Model II regression of number of ovicells against number of zooids in Celleporella yagana ( $\bullet \mathrm{Y}=0.191 \mathrm{X}$ $-39.642 ; 95 \%$ CI for the slope: 0.151 to 0.232 ) and $C$. patagonica (A; $\mathrm{Y}=0.446 \mathrm{X}-53.567 ; 95 \% \mathrm{CI}$ for the slope: 0.388 to 0.506 )

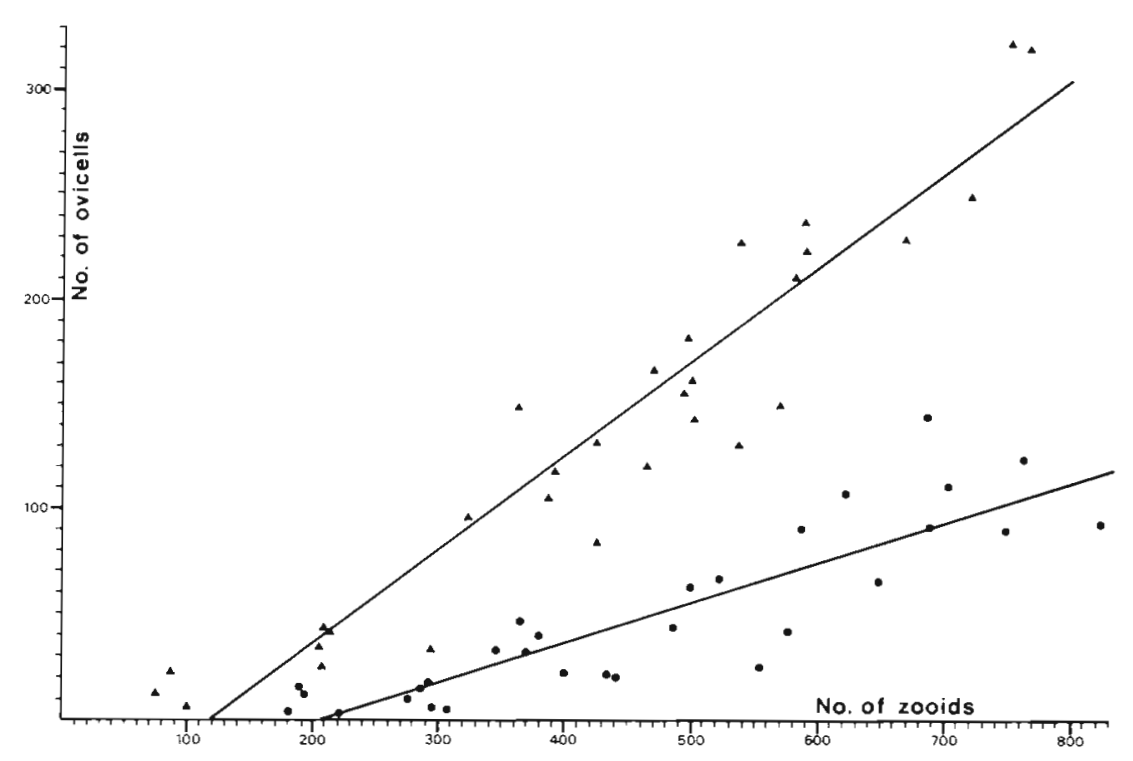

influencing the structure of communities of sessile colonial invertebrates have been recently analyzed in simulation studies (Karlson \& Jackson 1981, Karlson \& Buss 1984, Karlson 1985).

Analysis of overgrowth data in Fig. 2, as well as values for the intransitivity index, clearly indicate that the competitive organization in this bryozoan assemblage is essentially hierarchical. Absence of intransitive competitive relationships could be related to the very low proportion of lateral and rear encounters. Jackson (1979a), Buss (1981) and Rubin (1982) have pointed out the importance of the encounter angle in overgrowth competition. While in frontal encounters both growing edges meet, flank and rear encounters involve a higher proportion of growing edge to non-growing edge interactions, increasing the percentage of reversals.

Lack of intransitivity may also be related to the absence of sponges. Jackson \& Buss (1975) and Buss (1976) have reported that several sponges exhibit species-specific allelochemical effects, which may provide mechanisms for the occurrence of complex competitive networks in marine epifaunal communities.

Vertical relief of the colony has been regarded as an important factor influencing the competitive capability of a bryozoan species (Buss 1980a). The present study shows a clear correlation between zoarial height and $W / L$ ratio values for cheilostomes but not for cyclostomes. The poor competitive performance of the latter against cheilostome bryozoans has been already pointed out by Harmelin (1976) in his detailed ecological study of the Mediterranean fauna.

Present results also indicate that colony size has a minor importance when interacting species have very different overgrowth abilities. In contrast, when overgrowth capabilities are equal, colony size strongly itivity, disturbance, recruitment rates and other factors 
influences the outcome of the encounter The interactions of Umbonula alvareziana with Exochella longirostris and Smittina monacha are good examples of this. Factors accounting for the success of the former are not only to be found in morphologic characteristics of its zooids. Either by growing faster or settling earlier on the substratum, zoaria of $U$. alvareziana are able to attain a larger size before meeting other competitively equivalent species like $E$. longirostris and S. monacha.

This study confirms the results reported by Russ (1982) about the outcome in interactions between species belonging to different taxonomic groups. There is a clear dominance of tunicates over bryozoans, and of the latter over spirorbids, which makes the occurrence of reversals or loops between members of different phyla very unlikely. Reversals have only been observed within the Bryozoa, and particularly between species with similar overgrowth capabilities.

The protrusion of the apertures above an overgrowing colony observed in Patagonian spirorbids has been previously described for other tube-building polychaetes by Stebbing (1973a), Osman (1977) and Keen \& Neill (1980). Since in this way large individuals appear to avoid overgrowth by bryozoans more frequently than smaller ones, it could be considered as another example of escape in size, a mechanism providing refuge in competition for space between sessile organisms (Jackson 1977a, Sebens 1982). Fouling spirorbids cannot be regarded as a source of mortality for bryozoans. Owing to their small size, it is unlikely that more than a few zooidal apertures in the central part of the zoarium could be occluded. Palumbi \& Jackson (1983) have reported that proximal, senescent areas of Steginoporella sp. are also more heavily fouled by epibionts compared to younger zones of the colonies.

Homosyndrome (Knight-Jones \& Moyse 1961), i.e. the fusion of separate zoaria originating from different larvae of the same species, is a well-documented phenomenon in bryozoans. It was observed for the first time in Chilean populations of Membranipora hyadesi (Moyano 1967), and later reported in the cheilostomes Membranipora membranacea, Parasmittina trispinosa (Stebbing 1973b) and Parasmittina nitida (Humphries 1979), the cyclostomes Microecia suborbicularis and Diplosolen obelium (Harmelin 1976) and the Permian fenestrate Septopora sp. (McKinney 1981). Although the cases of fusion in Umbonula alvareziana observed in the present study appear to be total, the existence of communication organs in the line of contact between zooids of both colonies could not be confirmed.

The absence of correlation between percentage cover and overgrowth ability observed in the present study may be related to the relatively early successional stage of this community, in which bare space and fugitive species such as Celleporella patagonica still occupy a considerable proportion of the surface. A completely different pattern has been found by Keen \& Neill (1980) in a bryozoan-dominated assemblage settled on concrete blocks after 3 yr of exposure. In this case rarity was associated with lowest overgrowth incidence, while numerically predominant species showed the highest overgrowth ability.

Colony shape and growing pattern are fundamental characteristics determining the way in which a bryozoan species competes for space in an epifaunal community (Jackson 1979b, 1981). It is interesting to note how different morphological strategies have evolved within the cheilostome genus Celleporella. Of the 4 species represented in this assemblage, only C. hyalina was a successful competitor, while the other 3 species have, together with Tubulipora organisans, the lowest values for the $\mathrm{W} / \mathrm{L}$ ratio. The relatively high $\mathrm{W} / \mathrm{L}$ ratio of $C$. hyalina could be related to the multilayered structure of its colonies. Whereas the basal layer is composed of autozooids, male and female zooids develop from frontally directed pore chambers located near the proximolateral margins of the zooids (Lidgard $1985 a$ a). In addition to its defensive functions in overgrowth competition, budding of multilayered colonies is a normal process in the astogeny of $C$. hyalina. Indeed, it was observed in all colonies which had attained a considerable size, even in those not threatened by overgrowth by neighbouring competitors. On the other hand, frontal budding in Smittina monacha has different characteristics. Buds arise from the upward growth of the membranous cuticular wall that covers the hypostegal coelom. Following a budding process which has been well studied in other cheilostome species (Banta 1972, Lidgard 1985a, b), the hypostega begins to expand and finally forms the bud that will become the new zooid. The development of frontal budding was not frequent in the present $S$. monacha, and appears to have been a response to overgrowth, since it was observed only in cases of particularly intense competition, in which growth of the basal layer was almost totally obstructed.

Celleporella yagana, C. patagonica and C. bougainvillei are very abundant in different subtidal environments in Puerto Deseado, particularly on red and brown algae (López Gappa et al. 1982, López Gappa 1985), most of which have relatively short life-cycles The low overgrowth abilities of $C$. yagana and $C$. patagonica, together with their high percentage cover on panels, suggest that they are adapted to colonizing new substrata during early stages of succession, becoming sexually mature before being overgrown by other competitors. Both species are very closely related, having in common a peculiar tatiform ancestrula, and were only recently recognized as 2 different taxonomic entities (Moyano \& Gordon 1980, López Gappa 1985. 
Moyano 1986). The interaction between these $2 \mathrm{r}$ selected species is a good example of competitive dominance of sheet-like zoaria over runner-like ones, since $C$. patagonica and C. yagana have a similar zooidal morphology but differ mainly in their astogenies and colony shapes. The fugitive strategy displayed by $C$. patagonica is therefore consistent with the model developed by Buss (1979), which predicts that runner-like forms should exhibit higher recruitment and growth rates, but lower interference competitive capabilities, than sheet-like forms. Recruitment and growth rates are still unknown in these 2 species. However, it is clear from present evidence that $C$. patagonica compensates its poor competitive performance by reaching sexual maturity earlier and having a significantly higher rate of ovicell production.

Acknowledgements. I thank Alejandro Tablado, Elena Mostajo, Victoria Lichtschein, Prof. S. Gerlach and 2 anonymous reviewers for critical reading of the manuscript. I am also grateful to Mercedes Ichazo for taxonomic identification of the polychaetes. This work was supported by the Consejo Nacional de Investigaciones Científicas y Técnicas (CONICET, grant No. 9780/86).

\section{LITERATURE CITED}

Banta, W. C. (1972). The body wall of chellostome Bryozoa, V. Frontal budding in Schizoporella unicornis floridana. Mar. Biol. 14: 63-71

Buss, L. W (1976). Better living through chemistry: the relationship between competitive networks and allelochemical interactions. In: Harrison, F. W., Cowden, R. R. (eds.) Aspects of sponge biology. Academic Press, New York, p. $315-327$

Buss, L. W. (1979). Habitat selection, directional growth and spatial refuges: why colonial animals have more hiding places. In: Larwood, G. P., Rosen, B. R. (eds.) Biology and systematics of colonial organisms. Academic Press, London. p. $459-497$

Buss, L. W (1980a). Competitive intransitivity and size-frequency distributions of interacting populations. Proc. natn. Acad. Sci. U. S. A. 77: 5355-5359

Buss, L. W. (1980b). Bryozoan overgrowth interactions - the interdependence of competition for space and food. Nature, Lond. 281: 475-477

Buss, L. W. (1981). Mechanisms of competition between Onychocella alula (Hastings) and Antropora tincta (Hastings) on an Eastern Pacific rocky shoreline. In: Larwood, G. P., Nielsen, C. (eds.) Recent and fossil Bryozoa. Olsen \& Olsen, Fredensborg, p. 39-49

Buss, L. W., Jackson, J. B. C. (1979). Competitive networks: nontransitive competitive relationships in cryptic coral reef environments. Am. Nat. 113: 223-234

Cancino, J. M. (1986). Marine macroalgae as a substratum for sessile invertebrates: a study of Celleporella hyalina (Bryozoa) on fronds of Laminaria saccharina (Phaeophyta). Monogr. biol. 4: 279-308

Connell, J. H. (1961). The influence of interspecific competition and other factors on the distribution of the barnacle Chtamalus stellatus. Ecology 42: 710-723

Dayton, P. K. (1971). Competition, disturbance and commun- ity organization: the provision and subsequent utilization of space in a rocky intertidal community. Ecol. Monogr. 41 351-389

Gordon, D. P. (1972). Biological relationships of an intertidal bryozoan population. J. nat. Hist. 6: 503-514

Harmelin, J.-G. (1976). Le sous-ordre des Tubuliporina (Bryozoaires Cyclostomes) en Méditerrannée. Ecologie et systématique Mem. Inst. Océan. 10, $326 \mathrm{p}$.

Hayward, P. J. (1973). Preliminary observations on settlement and growth in populations of Alcyonidium hirsutum (Fleming). In: Larwood, G. P. (ed.) Living and fossil Bryozoa. Academic Press. London, p. 107-113

Humphries, E. M. (1979). Selected features of growth in Parasmittina nitida. In: Larwood, G. P., Abbott, M. B. (eds.) Advances in bryozoology. Academic Press, London, p. $195-218$

Jackson, J. B. C. (1977a). Competition on marine hard substrata: the adaptive significance of solitary and colonial strategies. Am. Nat. 111: 743-767

Jackson, J. B. C. (1977b). Habitat area, colonization, and development of epibenthic community structure. In: Keegan, B. F., Ceidigh, P. O., Boaden, P. J. S. (eds.) Biology of benthic organisms. Pergamon Press, London, p. 349-358

Jackson, J. B. C. (1979a). Overgrowth competition between encrusting ectoprocts in a Jamaican cryptic reef environment. J. Anim. Ecol. 48: 805-823

Jackson, J. B. C. (1979b). Morphological strategies of sessile animals. In: Larwood, G. P., Rosen, B. R. (eds.) Biology and systematics of colonial organisms. Academic Press, London, p. 499-555

Jackson, J. B. C. (1981). Competitive interactions between bryozoans and other organisms. In: Broadhead, T W (ed.) Lophophorates. Notes for a short course. Univ. Tenn. Dept. Geol. Sci., Stud Geol. 5: 22-36

Jackson, J. B. C., Buss, L. W (1975). Allelopathy and spatial competition among coral reef invertebrates. Proc natn. Acad. Sci. U.S.A. 72: 5160-5163

Karlson, R. H. (1985). Competitive overgrowth interactions among sessile colonial invertebrates: a comparison of stochastic and phenotypic variation. Ecol. Modelling 27 : 299-312

Karlson, R. H., Buss, L. W. (1984). Competition, disturbance and local diversity patterns of substratum-bound clonal organisms: a simulation. Ecol. Modelling 23: 243-255

Karlson, R. H., Jackson, J. B. C. (1981). Competitive networks and community structure: a simulation study. Ecology 62 $670-678$

Karlson, R. H., Shenk, M. A. (1983). Epifaunal abundance, association. and overgrowth patterns on large hermit crab shells. J. exp. mar Biol. Ecol. 70: 55-64

Keen, S. L., Neill, W E. (1980). Spatial relationships and some structuring processes in benthic intertidal animal communities. J. exp. mar. Biol. Ecol. 45: 139-155

Knight-Jones, E. W., Moyse, J. (1961). Intraspecific competition in sedentary marine animals. Symp. Soc. exp. Biol. 15: 72-95

Kühnemann, O. (1970). Vegetación marina de la ría de Puerto Deseado. Opera Lilloana 17: 1-123

Liddell, W. D., Brett, C. E. (1982). Skeletal overgrowths among epizoans from the Silurian (Wenlockian) Waldron Shale. Paleobiology 8: 67-78

Lidgard, S. (1985a). Budding process and geometry in encrusting cheilostome bryozoans. In: Neilsen, C., Larwood, G. P. (eds.) Bryozoa: Ordovician to Recent. Olsen \& Olsen, Fredensborg, p. 175-182

Lidgard, S. (1985b). Zooid and colony growth in encrusting cheilostome bryozoans. Palaeontology 28: 255--291

López Gappa, J. J. (1985). Briozoos marinos de la ría Deseado 
(Santa Cruz, Argentina). II. Familia Hippothoidae. Physis Secc. A. Oceanos sus. Org. 43: 51-63

López Gappa, J. J., Romanello, E. E., Hernández, D. A. (1982). Observaciones sobre la macrofauna y flora asociadas a los grampones de Macrocystis pyrifera (L.) C. Ag. en la ría Deseado (Santa Cruz, Argentina). Ecosur 9: 67-106

McKinney, F. K. (1981). Intercolony fusion suggests polyembriony in Paleozoic fenestrate bryozoans. Paleobiology 7 : $247-251$

Moyano, H. I. (1967). Sobre la fusión de dos colonias de Membranipora hyadesi Jullien, 1888. Not mens. Mus. Nac. Hist. nat. $126,4 \mathrm{p}$.

Moyano, H. I. (1986). Bryozoa marinos chilenos VI. Cheilostomata Hippothoidae: South Eastern Pacific species. Boln. Soc. Biol. Concepción 57. 89-135

Moyano, H. I., Gordon, D. P. (1980). New species of Hippothoidae (Bryozoa) from Chile, Antarctica and New Zealand. J. R. Soc. N.Z. 10: 75-95

O'Connor, R. J., Seed, R., Boaden, P. J. S. (1980). Resource space partitioning by the Bryozoa of a Fucus serratus $\mathrm{L}$. community. J. exp. mar. Biol. Ecol. 45: 117-137

Osman, R. W. (1977). The establishment and development of a marine epifaunal community. Ecol. Monogr. 47 37-63

Paine, R. T. (1966). Food web complexity and species diversity. Am. Nat. 100: 65-75

Paine, R. T (1971). A short-term experimental investigation of resource partitioning in a New Zealand rocky intertidal habitat. Ecology 52: 1096-1106

Paine, R. T (1974). Intertidal community structure: experimental studies on the relationship between a dominant competitor and its principal predator. Oecologia (Berl.) 15: 93-120

Paine, R. I (1984). Ecological determinism in the competition for space. Ecology 65: 1339-1348

Palumbi, S. R., Jackson, J. B. C. (1983). Aging in modular organisms: ecology of zooid senescence in Steginoporella sp. (Bryozoa: Cheilostomata). Biol Bull. mar. biol. Lab., Woods Hole 164: 267-278

Quinn, J. F. (1982). Competitive hierarchies in marine benthic communities. Oecologia (Berl.) 54: 129-135
Rohlt, F. J. (1982). BIOM. A package of statistical programs to accompany the text Biometry. Department of Ecology and Evolution, State University of New York, Stony Brook

Rubin, J. A. (1982). The degree of intransitivity and its measurement in an assemblage of encrusting Cheilostome Bryozoa. J. exp. mar Biol. Ecol. 60: 119-128

Russ, G. R. (1980). Effects of predation by fishes, competition, and structural complexity of the substratum on the establishment of a marine epifaunal community. J. exp. mar. Biol. Ecol. 42: 55-69

Russ, G. R. (1982). Overgrowth in a marine epifaunal community: competitive hierarchies and competitive networks. Oecologia (Berl.) 53: 12-19

Sebens, K. P. (1982). Competition for space: growth rate, reproductive output, and escape in size. Am. Nat. 120 189-197

Seed, R., O'Connor, R. J. (1981). Community organization in marine algal epifaunas. Ann. Rev. Ecol. Syst. 12: 49-74

Siegel, S. (1956). Nonparametric statistics for the behavioral sciences. McGraw-Hill, New York

Sokal, R. R., Rohlf, F. J. (1981). Biometry, the principles and practice of statistics in biological research, 2nd edn. W. H Freeman \& Co., San Francisco

Stebbing, A. R. D. (1973a). Competition for space between the epiphytes of Fucus serratus L. J. mar biol. Ass. U.K. 53: $247-261$

Stebbing, A. R. D. (1973b). Observations on colony overgrowth and spatial competition. In: Larwood, G. P. (ed.) Living and fossil Bryozoa. Academic Press, London, p. 173-183

Sutherland, J. P., Karlson, R. H. (1977). Development and stability of the fouling community at Beaufort, North Carolina. Ecol. Monogr. 47: 425-446

Taylor, P. D. (1979). Palaeoecology of the encrusting epifauna of some British Jurassic bivalves. Palaeogeogr., Palaeoclimatol. Palaeoecol. 28: 241-262

Taylor, P. D. (1984). Adaptations for spatial competition and utilization in Silurian encrusting bryozoans. Spec. Pap. Palaeontol. 32: 197-210 